Srđan Matijašević ${ }^{*}$, Snežana Zildžović ${ }^{1}$,

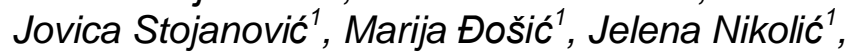
Mirjana Stojanović ${ }^{1}$, Nebojša Labus ${ }^{2}$

${ }^{1}$ Institute for Technology of Nuclear and Other Mineral Raw Materials, Belgrade, Serbia, Institute of Technical Sciences of the Serbian Academy of Sciences and Arts, Belgrade, Serbia
Scientific paper ISSN 0351-9465, E-ISSN 2466-2585 UDC:549.67:628.161.3 doi:10.5937/ZasMat1604551M



Zastita Materijala 57 (4) 551 - 558 (2016)

\title{
Removal of uranium (VI) from aqueous solution by acid modified zeolites
}

\begin{abstract}
The objective of this study was the review of natural zeolite, modified with acid, as a candidate material for the remediation of groundwater contaminated by uranium(VI).

The modified zeolite samples were obtained by treatment of natural zeolite - clinoptilolite with acids: hydrochloric, oxalyc and citric. Starting and modified zeolites were characterized by chemical analysis, SEM, XRPD analysis, IR spectroscopy, thermal (TG/DT) analysis and by determination of cation exchange capacity, while starting and nonadsorbed amounts of uranium(VI) ion were determined by fluorometric method. Batch experiments were conducted to investigate the effect of solid/liquid ratio, $\mathrm{pH}$ and time on the U(VI) uptake by zeolite. Modification of zeolitic tuff with acids significantly increased adsorption of uranium(VI). The highest adsorption of uranium(VI) ion was achieved on clinoptilolite modified with hydrochloric acid.

Uranium(VI) adsorption data for zeolite modified with hydrochloric acid was fitted to the Langmuir model.
\end{abstract}

Keywords: zeolite - clinoptilolite, acid modification, uranium(VI) adsorption.

\section{INTRODUCTION}

Zeolites are natural and synthetic crystalline, micro-porous, aluminosilicates of alkali and alkaline earth cations. Natural zeolites are formed as a result of chemical reactions of the volcanic ash and alkaline water a few thousand millennia ago. They have been used in various parts of the world for centuries [1].

The fundamental building block of the zeolites is a tetrahedron of four oxygen atoms surrounding a relatively small silicon or aluminum atom. Zeolite frameworks are formed of $\mathrm{SiO}_{4}$ and $\mathrm{AlO}_{4}$ tetrahedra linked by oxygen atoms, which share all four corners. These can combine in many ways, giving rise to a large number of different zeolite structures. In the zeolite framework, each aluminum atom introduces one negative charge on the framework which must be balanced by the exchangeable cations $\left(\mathrm{Na}^{+}, \mathrm{K}^{+}, \mathrm{Ca}^{2+}, \mathrm{Mg}^{2+}\right.$, etc.). These univalent

${ }^{*}$ Corresponding author: Srđan Matijašević

E-mail: s.matijasevic@itnms.ac.rs

Paper received: 24. 05. 2016.

Paper accepted: 22. 07. 2016.

Paper is available on the website: www.idk.org.rs/journal and/or bivalent metal cations may be replaced via ion-exchange to other ions. Substitution of $\mathrm{Al}^{3+}$ for other cations $(\mathrm{Ge}, \mathrm{Fe})$ is possible mainly in natural zeolites. The physical structure is porous with interconnected cavities in which metal cations and water molecules are contained. The zeolites have reversible hydration properties in addition to their cation exchange properties.

Clinoptilolite, one of the most commonly observed natural zeolite mineral, whose empirical formula is $(\mathrm{Na}, \mathrm{K})_{6}\left[\left(\mathrm{AlO}_{2}\right)_{6}\left(\mathrm{SiO}_{2}\right)_{30}\right] \cdot 24 \mathrm{H}_{2} \mathrm{O}$, is an isostructural variant of heulandite, $\mathrm{Ca}_{4}\left[\left(\mathrm{AlO}_{2}\right)_{8}\left(\mathrm{SiO}_{2}\right)_{28}\right] \cdot 24 \mathrm{H}_{2} \mathrm{O}$ [2]. The secondary structural heulandite units are arranged like sheets, which provides an explanation for the splitting properties of these zeolites. Shape and size of hollows and channels, as well as their interrelations, are constant and precisely defined as structural parameters of a certain zeolite type. Clinoptilolite has variety of applications because of abundance and its chemical properties. Extensive deposits clinoptilolite are found in the United States, Canada, Russia, Bulgaria, Romania, Hungary, Serbia, Ukraine, Turkey, Lebanon, India, Australia, China and Japan. 
Due to their specific porous structure and chemical and physical properties, natural zeolites have found applications in the field of selective sorption gases, vapors and liquids, catalytic activities, pollution control, including control of hardness, heavy metals, ammonia removal, air pollutants and radioactive contaminants $[3,4,5]$.

Uranium is a toxic radioactive element and it is usually found in the environment in the hexavalent form released often from nuclear industry, mining and milling facilities. The toxic nature of uranium (VI) ions, even at trace levels, has been a public health problem for many years. The research of separation and removal of uranium from wastewater is important not only for the nuclear industry, but also for environmental remediation. Uranyl ion has been shown to be strongly sorbed onto many soil constituents including clay minerals and metal oxides under appropriate chemical conditions, and therefore such materials can be used for uranium (VI) remediation of aqueous solutions [6, 7]. The extent that uranium $(\mathrm{VI})$ is removed from aqueous solutions is a function of the aqueous solution properties such as $\mathrm{pH}$, uranium( $\mathrm{VI})$ concentration, complexing ligands and the sorptive phase characteristics. Previous research based on chemical analysis explains adsorption of uranyl ions on modified zeolitic tuff [8].

In this paper the investigation results of physico-chemical characterization and adsorption of uranium( $\mathrm{VI})$ on natural and acids modified zeolitic mineral clinoptilolite/heulandite are presented.

\section{EXPERIMENTAL}

Starting material (denoted as Ca-clino) used in these experiments was natural zeolitic tuff from Beočin deposit (Fruška Gora, Serbia), split to a granulation finer than $100 \mu \mathrm{m}$. The hydrochloric acid $(1 \mathrm{M})$, oxalyc acid $(0.5 \mathrm{M})$, citric acid $(0.33 \mathrm{M})$ was used for the preparation of the acid modified zeolite. All reagents used in this study were analytical grade. The constant quantity of zeolitic tuff $(100 \mathrm{~g})$ was treated with $1000 \mathrm{ml}$ of acids solution for 60 minutes at $50^{\circ} \mathrm{C}$. After mixing, the suspension was filtrated and the concentrations of exchanged $\mathrm{Ca}^{2+}, \mathrm{Mg}^{2+}, \mathrm{Na}^{+}$and $\mathrm{K}^{+}$were measured in the supernatant using atomic absorption spectrophotometry (AAS Perkin Elmer 703). The acid modified zeolite was rinsed with distilled water until $\mathrm{Cl}^{-}$-ions or $\mathrm{C}_{2} \mathrm{O}_{4}{ }^{2-}$ and $\mathrm{H}_{5} \mathrm{C}_{6} \mathrm{O}_{7}{ }^{3-}$ were no longer detected and then dried at $105^{\circ} \mathrm{C}$. These product was denoted as $\mathrm{H}$-clino, $\mathrm{OH}$-clino and $\mathrm{LH}$-clino respectively.

Scanning electron microscope (SEM) images were taken using a Jeol JSM-6460/LV scanning electron microscope. The images were taken to study the surface morphology of zeolite particles.

XRPD analyses of starting zeolitic tuff and acid treated samples were performed on the Phillips $\mathrm{PW} / 1710$ diffractometer with monochromatic $\mathrm{Cu} / \mathrm{K} \alpha$ radiation, in the range of $4^{\circ}-65^{\circ} 2 \theta$.

Infrared spectral studies provide information about the polyhedral framework structure and composition of zeolites. It was performed on Perkin Elmer 782 in the range $4000-250 \mathrm{~cm}^{-1}$ using the $\mathrm{KBr}$ pellet technique.

Thermogravimetric and differential thermal analysis (TGA and DTA) were carried out on 100 mg sample at heating rate of $10^{\circ} \mathrm{Cmin}^{-1}$ on Netzsch STA 409EP. The analysis was conducted in air using corundum crucibles and employing $\mathrm{Al}_{2} \mathrm{O}_{3}$ as a reference standard.

Uranium (VI) solutions for adsorption experiments were prepared using uranyl nitrate hexahydrate $\left(\mathrm{UO}_{2}\left(\mathrm{NO}_{3}\right)_{2} \cdot 6 \mathrm{H}_{2} \mathrm{O}\right)$ (Sigma-Aldrich $\mathrm{Co})$. The preliminary batch studies were carried out by shaking known amounts of each adsorbent $(5 \mathrm{~g})$ and uranium(VI) solution, at room temperature for at least $2 \mathrm{~h}$, at $\mathrm{pH} 6$. In order to investigate influence of the amount of $\mathrm{H}$-clino, $\mathrm{OH}$-clino and $\mathrm{LH}$-clino in suspension on uranium( $\mathrm{VI})$ adsorption, at $\mathrm{pH} \mathrm{6}$, the experiments were performed as follows: the volume of solution $(50 \mathrm{ml})$ and the concentration of uranium $(\mathrm{VI})(50 \mathrm{mg} / \mathrm{L})$ were kept constant while the amount of adsorbent varied from 0.5 to $2.5 \mathrm{~g}$ (solid:liquid ratio $10-50 \mathrm{~g} / \mathrm{L}$ ). The suspensions were shaken for $2 \mathrm{~h}$, at room temperature. After the reaction time, the solids were separated by filtration and in supernatants, the remained uranium $(\mathrm{VI})$ concentration was determined.

In order to investigate uranium(VI) adsorption isotherms on $\mathrm{H}$-zeolites, to each tube $0.125 \mathrm{~g}$ of adsorbent and $50 \mathrm{ml}$ of uranium( $\mathrm{VI})$ solution were added at concentration of $10,20,25,30,40,50$ $\mathrm{mg} / \mathrm{L}$. The adsorption of uranium $(\mathrm{VI})$ ion on $\mathrm{H}, \mathrm{OH}$ and $\mathrm{LH}$-clino were studied at different $\mathrm{pH}$ values, with each sample being done in duplicate.

Since, at $\mathrm{pH}$ values higher than 8.5, precipitaton of a yellow uranyl carbonate complex was noticed, all experiments were performed in $\mathrm{pH}$ range from 3 to 8 .

The $\mathrm{pH}$ was adjusted with $\mathrm{HNO}_{3}$ and $\mathrm{NaOH}$. Samples were shaken for $2 \mathrm{~h}$, solutions were filtered through a Whatman No.42 filter paper and uranium(VI) concentration were measured in supernatants.

Initial uranium $(\mathrm{VI})$ concentrations, as well as equilibrium uranium(VI) concentration in solutions 
were determined using fluorometric method based on the fluorescence of $\mathrm{U}$ in fused mixture of $\mathrm{NaF}$, $\mathrm{Na}_{2} \mathrm{CO}_{3}$ and $\mathrm{K}_{2} \mathrm{CO}_{3}[9]$.

\section{RESULTS AND DISCUSSION}

$X$-ray diffraction analysis was used to determine the qualitative mineralogical composition of the clinoptilolite tuff. Based on qualitative mineralogical analysis, the content of clinoptilolite/heulandite in natural zeolitic tuff was over $80 \%$, while the accessory minerals were quartz, feldspar, mica, calcite and clay minerals. Calcium was the dominant ion in exchangeable possition. The starting material has the following chemical composition: $\mathrm{SiO}_{2}-56.00 \%, \mathrm{Al}_{2} \mathrm{O}_{3}-14.40 \%$, $\mathrm{Fe}_{2} \mathrm{O}_{3}-1.84 \%$, $\mathrm{CaO}-6.20 \%, \mathrm{MgO}-2.64 \%, \quad \mathrm{Na}_{2} \mathrm{O}-$ $0.52 \%, \mathrm{~K}_{2} \mathrm{O}-2.32 \%$, I.L. $-15.50 \%$. The granules of the sample were equal to $0-0.100 \mathrm{~mm}$. The SEM pictures of the parent $\mathrm{Ca}$-clino and $\mathrm{H}$-clino zeolites are shown in Figure 1. Figure 1a, shows the SEM image of starting sample Ca-clino.
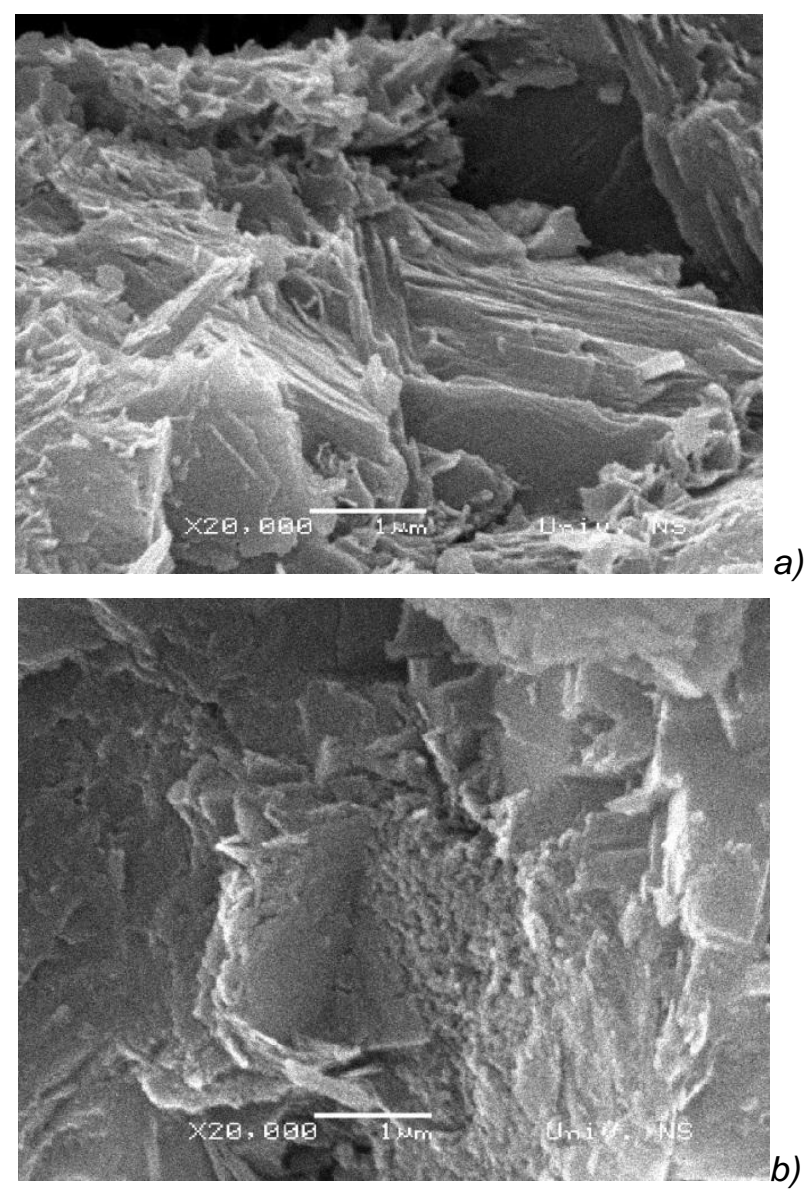

Figure 1 - SEM micrograph of the starting sample $1 \mathrm{a}$ and acid modified zeolite $\mathrm{H}$-clino $\mathrm{1b}$, magnification $(20000 \mathrm{x}$ )

The picture shows that the aggregates of the particles and the morphology of particles. Figure
$1 \mathrm{~b}$, shows the SEM image of hydrochloric acid modified zeolite, $\mathrm{H}$-clino.

The modification of $\mathrm{H}$-clino zeolite might have resulted in structural degradation of the parent zeolite. This figures illustrates the surface irregularity and the existence of pores on the adsorbent.

The cation exchange capacity (CEC) of the zeolitic tuff was:168 meq/100g in exchangeable position and 251 in non exchangeable, $\quad \Sigma 419$ $\mathrm{meq} / 100 \mathrm{~g}(\mathrm{H}$-clino were $220 \mathrm{meq} / 100 \mathrm{~g}$, OH-clino $122 \mathrm{meq} / 100 \mathrm{~g}$ and LH-clino $108 \mathrm{meq} / 100 \mathrm{~g}$ ) and the external cation exchange capacity (ECEC) was $10.5 \mathrm{meq} / 100 \mathrm{~g}$. The CEC of clinoptilite rich tuff was measured with $1 \mathrm{M} \mathrm{NH} \mathrm{NH}_{4} \mathrm{Cl}$ while its ECEC was determined using the method of Ming and Dixon [10]. The XRPD patterns of starting and acids modified zeolitic tuff are presented at Figure 2.

The XRD pattern in Figure 2 (Ca-clino) shows the high crystallinity of the starting material with the characteristic reflection peaks attributed to the clinoptilolite as a main mineral component at $2 \theta=9.88^{\circ}$ (HEU 020), $22.47^{\circ}$ (HEU 131) and $30.06^{\circ}$ (HEU 151) [11]. The XRPD pattern of acids modified zeolitic tuff shows a decrease in the intensity of the main clinoptilolite peaks, indicating a loss of crystallinity of the zeolitic tuff, particular for $\mathrm{H}$-clino. In addition, some slight changes in the position of the peaks were observed in the XRD patterns of acid treated samples. This can be related to both partial dealumination and the partial breakdown of the structure of the clinoptilolite. The treatment of the natural zeolitic tuff with $\mathrm{HCl}$ causes the dealumination (hydrolysis of $\mathrm{Al}-\mathrm{O}-\mathrm{Si}$ bonds) besides of the exchange of the zeolite cations by $\mathrm{H}^{+}$ions (decationization).

The treatment of the natural zeolitic tuff with $\mathrm{H}_{2} \mathrm{C}_{2} \mathrm{O}_{4}$ and $\mathrm{H}_{8} \mathrm{C}_{6} \mathrm{O}_{7}$ also causes decationization and the partial dealumination but less than $\mathrm{H}$-clino. The results suggest that acid treatments did not produce significant effects on the structure of $\mathrm{OH}$ clino and LH-clino but provokes the changes in the relative intensity of the diffraction peaks.

Figure 3 , shows infrared spectra of starting and acids modified zeolitic tuff.

IR results demonstrate that zeolites are significantly hydrated which is illustrated by a discrete water absorption bands in the 3600-3200 $\left(\mathrm{OH}\right.$-stretching) and $1620 \mathrm{~cm}^{-1}$ (H-O-H deformation) region (Figure 3 ). 


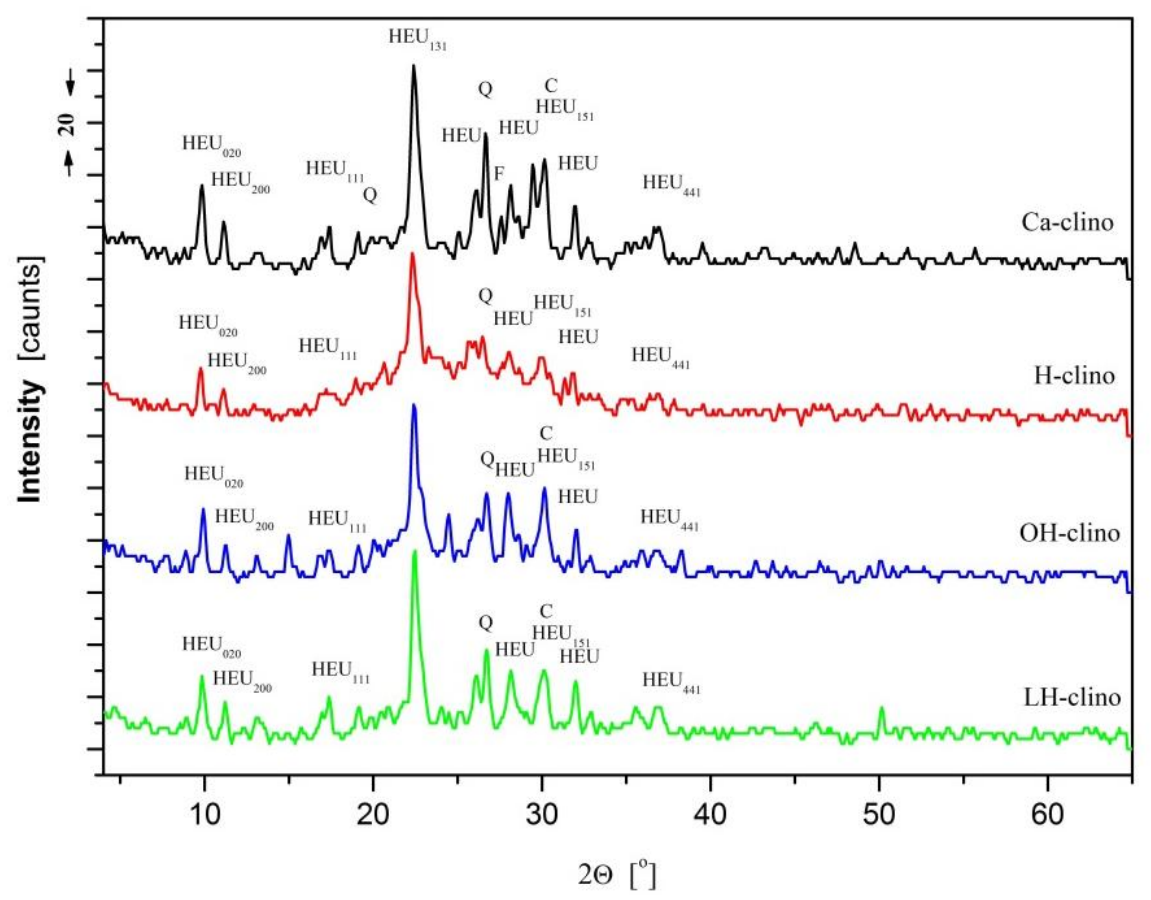

Figure 2 - XRPD patterns of starting zeolitic tuff and modified tuff with hydrochloric ( $\mathrm{H}$-clino), oxalyc $(\mathrm{OH}$ clino) and citric (LH-clino) acids

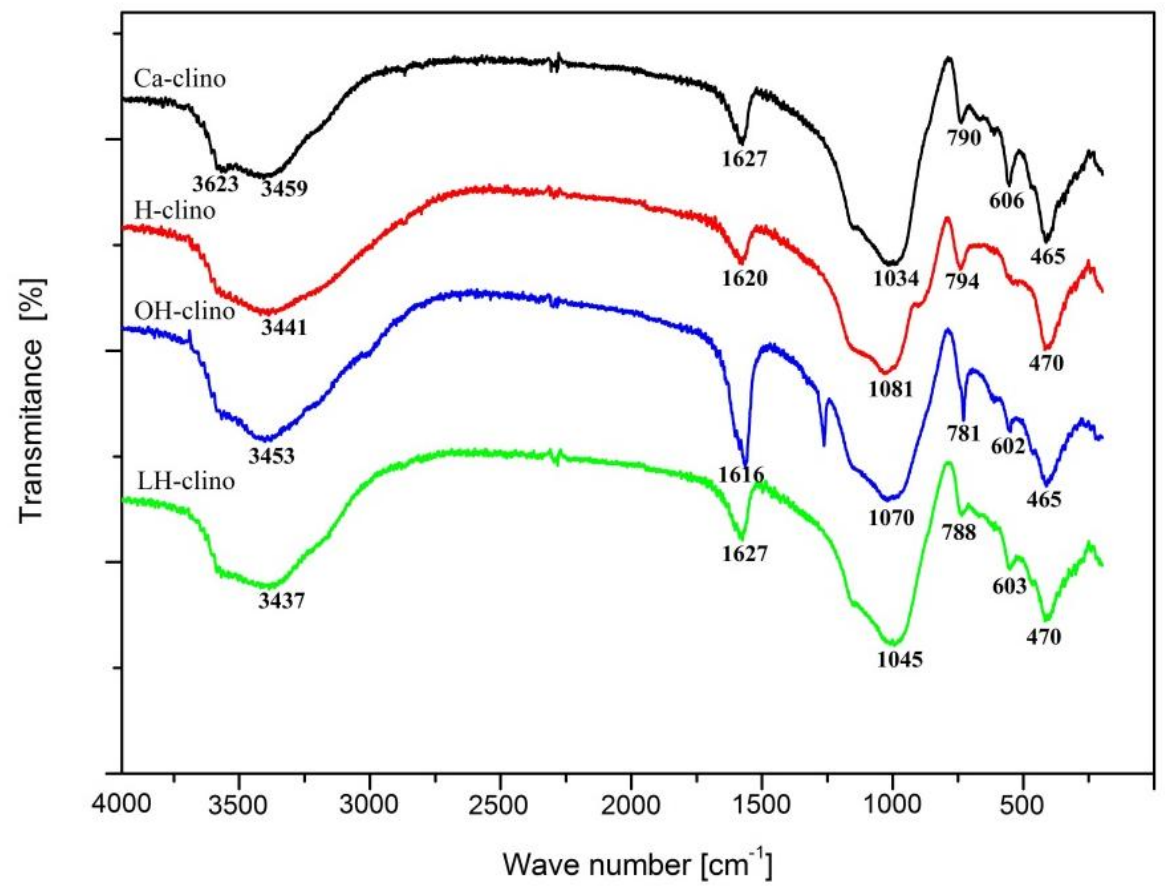

Figure 3 - Infrared spectra of starting and acid treating samples

The IR-spectrum of the acid treated samples (H-clino, OH-clino, LH-clino) showed marked changes of all vibration bands. For the zeolites prepared the strong bands at 1034 and $456 \mathrm{~cm}^{-1}$, assigned to a $\mathrm{T}-\mathrm{O}$ asymmetric stretching and $\mathrm{T}-\mathrm{O}$ bending vibrations of the internal tetrahedra, respectively, and the weak bands at 790 and 606 $\mathrm{cm}^{-1}$ wave numbers assigned to external symmetric stretching and double ring vibrations, respectively, were observed. The absorption band 
of the framework vibrations of raw zeolitic tuff (Caklino) are at approximately $1034 \mathrm{~cm}^{-1}$ (asymmetric internal $(\mathrm{Si}, \mathrm{Al})-\mathrm{O}$ stretching vibrations of the $(\mathrm{Al}$, $\mathrm{Si})-\mathrm{O}_{4}$ primary tetrahedral building units) [12]. This vibrations mode was shifted towards to higher frequencies $\left(1070 \mathrm{~cm}^{-1}\right.$ LH-clino, $1080 \mathrm{~cm}^{-1} \mathrm{H}$ clino) in the spectrum of the acids treated sample. This results corresponds to a partial structural breakdown, accompanied by the process of dealumination [13]. The band near $600 \mathrm{~cm}^{-1}$ disappeared after acid treatment with hydrochloric acid which is also indicative of dealumination and breakage of $\mathrm{Al}-\mathrm{O}$ bands inside the structure of zeolitic sample. In acid solutions, decationization and zeolite dealumination take place. Ion exchange is favored in the solutions with high acidity values, as zeolite decationization in such solutions is minimal $[14,15]$. The dissolution of natural zeolites, according to the Brønsted and Lewis theory, is the result of the acidic and basic behavior of the aluminosilicate structure in the presence of $\mathrm{H}^{+}$or $\mathrm{OH}^{-}$in the solutions. In acid solutions $\mathrm{Al}$ can be progressively removed from the aluminosilicate framework because of proton binding on the Lewis basic sites according to $>\mathrm{Al}-\mathrm{OH}+\mathrm{H}^{+} \rightarrow>\mathrm{AlOH}^{+}{ }_{2}$. The reactions are favored at lower $\mathrm{pH}$ values, and the $>\mathrm{AlOH}_{2}^{+}$species formed are detached because of their high degree of surface protonation $[16,17]$. Figure 4. shows TGA and DTA of starting and acid modified samples.

The presence of different exchangeable cations in zeolites leads to changes in temperature of zeolitic water elimination, which is held in a few stages $[8,18]$. TG curves of some forms of clinoptilolite are shown in Figure $4 \mathrm{a}$, respectively. As seen at TG curves, weight loss was continuous during heating up to $1000{ }^{\circ} \mathrm{C}$, due to dehydroxylation, dehydration and in Ca-clino and $\mathrm{OH}$-clino thermal decomposition of carbonates ( 15-17 wt.\%). Rapid weight loss was observed in the temperature range up to $400{ }^{\circ} \mathrm{C}$, a moderate one was recorded from 400 to $1000^{\circ} \mathrm{C}$.

In the case of $\mathrm{H}$-form of three sorbents, the elimination of intact water is observed up to $120^{\circ} \mathrm{C}$ that is caused by complex connectivity of pores and variation in their sizes as a result of exchangeable cation replacement with protons (Figure 4b). The difference in DTA curves for $\mathrm{OH}$ clino dealumination behavior can be explained by the dual nature of oxalic acid; it acts both as a hydrolysing and as a chelating agent forming a trioxalato aluminium complex with a high complexation constant $(\log \beta 3=15.1)$ [19].



a)

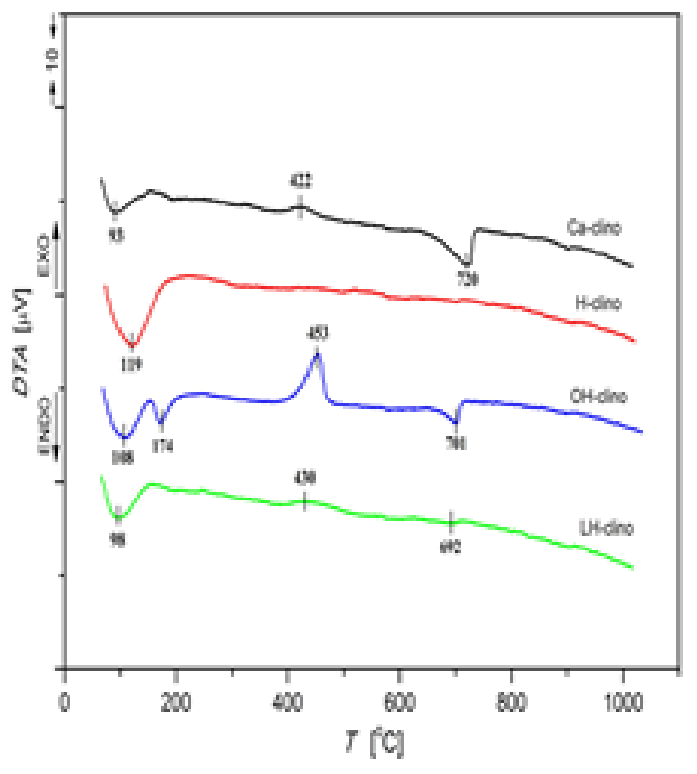

b)

Figure 4 - TGA and DTA curves

The dealumination mechanism proposed by Apelian et al. [20] involved two steps: first, aluminium was hydrolysed from the framework due to the acidity of the solution, and second, the aluminium cation was chelated by three oxalic acid molecules at surface of $\mathrm{OH}$-clino and indicated presence of endo effect at $174^{\circ} \mathrm{C}$ and exo efect at $453^{\circ} \mathrm{C}$ on DTA curve. The small endothermic peak at $\sim 700{ }^{\circ} \mathrm{C}$, (Figure $4 \mathrm{~b}$ ) can be attributed to the carbonates present in samples as it was shown by $\mathrm{X}$-ray analysis of samples.

\subsection{Adsorption studies}

The sorption studies were carried out at $25{ }^{\circ} \mathrm{C}$ to determine the sorption isotherms. In order to determine the equilibrium time for uranium(VI) 
adsorption on $\mathrm{H}$ modified-clino, the kinetics of adsorption was investigated. It was found that adsorption begins very fast and that the most of uranium( $\mathrm{VI})$ ion is adsorbed in less than 2 hours $(>95 \%)$. Practically there were no changes in adsorption within next $72 \mathrm{~h}$.

Table 1 - Uranium(VI) ion adsoption, solid:liquid ratio 50g/L

\begin{tabular}{|c|c|c|c|c|c|c|c|}
\hline \multicolumn{7}{|c|}{ Adsorption index, \% } \\
\hline Time & $15 \mathrm{~min}$ & $30 \mathrm{~min}$ & $1 \mathrm{~h}$ & $2 \mathrm{~h}$ & $24 \mathrm{~h}$ & $48 \mathrm{~h}$ & $72 \mathrm{~h}$ \\
\hline H-clino & 88.2 & 82.0 & 85.9 & 95.3 & 90.2 & 95.1 & 95.0 \\
\hline
\end{tabular}

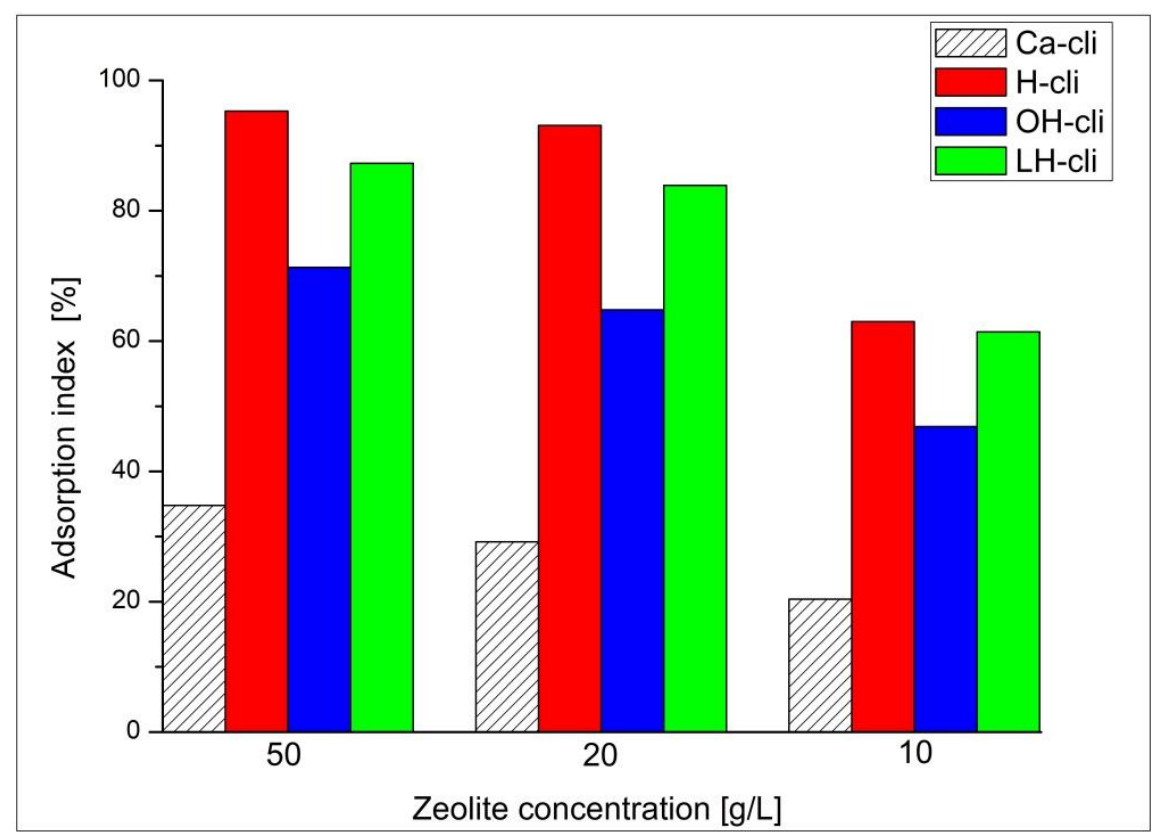

Figure 5 - Influence of the amount of $\mathrm{H}$-zeolite in suspension (solid:liquid ratio) on uranium (VI) adsorption, $p H=6, T=25^{\circ} \mathrm{C}$

Based on these results subsequent adsorption experiments were conducted with a 2 hours reaction time. Preliminary uranium(VI) ion adsorption experiments on natural unmodified zeolitic mineral (Ca-clino) at zeolite concentration $50 \mathrm{~g} / \mathrm{L}$, at $\mathrm{pH} 6$, showed that uranium (VI) adsorption index was $34.8 \%(0.34 \mathrm{mg}$ uranium $(\mathrm{VI}) / \mathrm{g}$ adsorbent), while uranium( $\mathrm{VI})$ adsorption on $\mathrm{H}$-clino, at $\mathrm{pH} \quad 6$, was $95.3 \% \quad(0.92 \mathrm{mg}$ uranium( $\mathrm{Vl}) / \mathrm{g}$ adsorbent), on $\mathrm{OH}-\mathrm{klino} 71.3 \%$ (0.69 $\mathrm{mg} / \mathrm{g}$ ) and LH-clino $87.1 \%(0.84 \mathrm{mg} / \mathrm{g})$. At zeolite concentration $20 \mathrm{~g} / \mathrm{L}$ and at concentration $10 \mathrm{~g} / \mathrm{L}$ adsorption index were lower (Figure 5).

From these results, it can be seen, that presence of $\mathrm{H}$-ions in zeolite increase uranium uptake significantly and decreasing the amount of acids modified zeolitic tuff in suspension, decrease the adsorption of uranium( $\mathrm{VI})$. The highest adsorption of uranium( $\mathrm{VI})$ ion was achieved on zeolite modified with hydrochloric acid ( $\mathrm{H}$-clino).

Acid treatment of natural zeolite has rendered improved sorbent, via the mechanism of decationation and dealumination. The cation blocking effects in treated zeolite is thus minimized by acid treatment [21]. Beside these factors, acid treatment can increase the pore volumes and specific surface area of zeolite.

Further results at constant mass of adsorbent $(0.125 \mathrm{~g})$ and varying concentrations of uranium(VI) in solution $(50 \mathrm{ml}$ of uranium $(\mathrm{VI})$, concentration 10 $50 \mathrm{mg} / \mathrm{L}$ ) and at three different $\mathrm{pH}$ are shown at the figure 6 . The isotherms were obtained by plotting the equilibrium concentration of uranium( $\mathrm{VI})$ in solution against the amount of uranium(VI) adsorbed per unit of weight of $\mathrm{H}$-zeolites. 


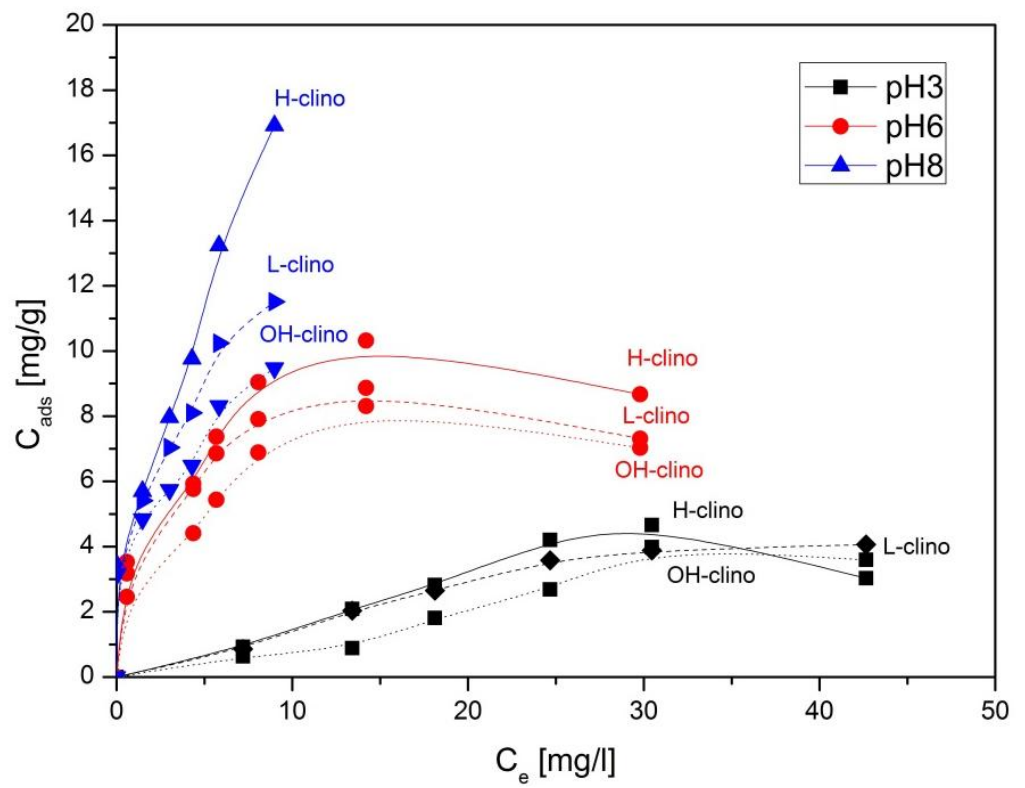

Figure 6 - Adsorption isotherms of uranium(VI) on $\mathrm{H}, \mathrm{OH}$ and L-clino, at different $\mathrm{pHs}, \mathrm{T}=25^{\circ} \mathrm{C}$

As can be seen from Figure 6, uranium(VI) adsorption on acid modified zeolites, according to IUPAC classification, is well described by the Langmuir type of isotherm, only at pH 6 (Type I). It can be noticed that the highest adsorption in all range of $\mathrm{pHs}(3-8)$ was achieved on $\mathrm{H}$-clino. The adsorption maximum calculated from Langmuir linear plot give estimates adsorption capacity for uranium( $\mathrm{VI})$ ion [22]. Calculated maximum of the $\mathrm{H}$ clino are $9.22 \mathrm{mg} / \mathrm{g}$ at $\mathrm{pH}$ 6. However, the highest adsorption of uranium $(\mathrm{VI})$ on $\mathrm{H}$-clino was achieved at $\mathrm{pH} 8(19.80 \mathrm{mg} / \mathrm{g}$ calculated). In acidic solution $(\mathrm{pH}=3)$, acid modified zeolite was less effective $(4.66 \mathrm{mg} / \mathrm{g}$ ) for the removal of uranium( $\mathrm{VI})$ from aqueous solutions.

Adsorption on $\mathrm{H}$-zeolite is strongly dependent on $\mathrm{pH}$ values. The sorption of uranium $(\mathrm{VI})$ ion increases quickly at $\mathrm{pH}$ 3-6 and reaches the maximum sorption near $\mathrm{pH}$ 8. Adsorption of uranium( $\mathrm{VI}$ ) ion on $\mathrm{H}$-zeolite following order $\mathrm{pH} 8>$ $\mathrm{pH} 6>\mathrm{pH} 3$ at different pHs.

\section{CONCLUSIONS}

A new adsorbent of acid treatment zeolites was obtained and the adsorption properties for uranium(VI) by $\mathrm{H}$-zeolites was investigated. Results demonstrated that presence of $\mathrm{H}$-ions in zeolite improve adsorption of uranium( $\mathrm{VI}$ ) ion significantly and that adsorption increase in following order $\mathrm{pH} 8>\mathrm{pH} 6>\mathrm{pH} 3$. The highest adsorption of uranyl ion was achieved on clinoptilolite modified with hydrochloric acid.

The results of this study indicate that acid modified natural clinoptilolite rich zeolitic tuff can be used for the uranium $(\mathrm{VI})$ removal from aqueous solutions in $\mathrm{pH}$ range 3-8.

\section{Acknowledgements}

This research was supported through the Ministry of Education and Science of the Republic of Serbia, under the Project 142057 and 34001.

\section{REFERENCES}

[1] G.Gottardi, E.Galli (1985) Natural Zeolites, Springer-Verlag, Berlin Heidelberg.

[2] D.W.Breck (1980) Zeolites: Molecular Sieves, Wiley-Interscience, New York.

[3] T.Armbruster (2001) Clinoptilolite-heulandite: applications and basic research, Studies in Surface Science and Catalysis, 135, 13-27.

[4] E.Chmielewska-Horvathova, J. Lesny (1995) Study of sorption equilibria in the systems: Water solutions of inorganic ions - Clinoptilolite, Journal of Radioanalytical and Nuclear Chemistry, 201(4), 293-301.

[5] E.Malliou, M.Loizidou, N.Spyrellis (1994) Uptake of lead and cadmium by clinoptilolite, Science of the Total Environment, 149, 139-144.

[6] E.R.Sylwester, E.A.Hudson, P.G.Allen (2000) The structure of uranium $(\mathrm{VI})$ sorption complexes on silica, alumina and montmorillonite, Geochimica et Cosmochimica Acta, 64(14), 2431-2438.

[7] A.Krestou, A.Xenidis, D.Panias (2003) Mechanism of aqueous uranium (VI) uptake by natural zeolitic tuff, Minerals Engineering, 16, 1363-1370.

[8] S.D.Matijašević, A.S.Daković, D.A.lleš, S.Z. Milićević (2009) Adsorption of uranyl ion on acidmodified zeolitic mineral clinoptilolite, Hemijska industrija, 63(5), 407-414. 
[9] S.Koički (1985) Hemijsko-tehnološki priručnik (2), Analitika, I.R.O. „Rad“, Beograd.

[10] D.W.Ming, J.B.Dixon (1986) Clinoptilolite in south Texas soils, Soil Science Society of America Journal, 50, 1618-1622.

[11] D.M.Moore, R.C.Reynolds (1997) X-ray Diffraction and the Identification and Analysis of Clay Minerals, 2nd edn., Oxford University Press, New York.

[12] G.Rodriquez-Fuentes, R.A.Ruiz-Salvodor, M.Mir, O. Picazo, G.Quintana, M.Delgado (1998) Thermal and cation influence on ir vibrations of modified natural clinoptilolite, Microporous and Mesoporous Materials, 20, 269-281.

[13] P.Misaelides, A.Godelitsas, F.Link, H.Baummann (1996) Application of the 27Al(p,y)28Si nuclear reaction to the characterization of the near-surface layers of acid-treated HEU-type zeolite crystals, Microporous Materials, 6, 37-42.

[14] V.J.Inglezakis, M.D.Loizidou H.P.Grigoropoulou (2003) lon exchange of $\mathrm{Pb}^{2+}, \mathrm{Cu}^{2+}, \mathrm{Fe}^{3+}$ and $\mathrm{Cr}^{3+}$ on natural clinoptilolite: selectivity determination and influence of acidity on metal uptake, Journal of Colloid and Interface, 261, 49-54.

[15] S.Kesraoui-Ouki, M.Kavannagh Performance of natural zeolites for the treatment of mixed metal-contaminated effluent, Waste Management and Research, 15, 383-394.
[16] K.V.Ragnarsdottir (1993) Dissolution kinetics of heulandite at $\mathrm{pH} 2-12$ and $25^{\circ} \mathrm{C}$. Geochimica et Cosmochimica Acta, 57, 2439-2449.

[17] M.S.Joshi, P.Mohan Rao (1983) Cation sieve properties of natural heulandite, Journal of Colloid and Interface Science, 95, 131-134.

[18] M.W.Kasture, P.N.Joshi, H.S.Soni, V.V.Joshi, A.L. Choudhari, V.P.Shiralkar (1998) Sorption properties of the natural, $\mathrm{K}$ and partially deammo-niated $\left(\mathrm{H} / \mathrm{NH}_{4}\right)$ forms of clinoptilolite, Adsorption Science and Technology, 16, 135-151.

[19] E.Bottari, L.Ciavatta (1968) Potentiometric study of Al(III)-oxalate complexes, Gazzetta Chimica Italiana, 98, 1004-1113.

[20] M.R.Apelian, A.S.Fung, G.J.Kennedy, T.F.Degnan (1996) Dealumination of zeolite $\beta$ via dicarboxylic acid treatment, Journal of Physical Chemistry, 100(41), 16577-16583.

[21] M.A.Hernandez, F.Rojas, V.H.Lara (2000) Nitrogen-sorption characterization of the microporous structure of clinoptilolite-type zeolites, Journal of Porous Materials, 7(4), 443-454.

[22] S.Matijašević, A.Daković, M.Tomašević-Čanović, M. Stojanović, D.lleš (2006) Uranium(VI) adsorption on surfactant modified heulandite/clinoptilolite rich tuff, Journal of the Serbian Chemical Society, 71(12), 1323-1331.

\section{IZVOD}

\section{UKLANJANJE URANIL-JONA IZ RASTVORA KISELO TRETIRANIM ZEOLITIMA}

Cilj ovog rada je prikaz mogućnosti primene prirodnog i modifikovanog zeolitskog minerala kao adsorbenta i materijala za sanaciju voda kontaminiranih uranijum jonom. Modifikovani uzorci zeolita dobijeni su tretiranjem prirodnog zeolita - klinoptilolita sa kiselinama: hlorovodoničnom, oksalnom i limunskom.

Polazni i modifikovani zeoliti su okarakterisani hemijskom analizom, skenirajućom elektronskom mikroskopijom (SEM), rendgenskom analizom (XRPD), IC spektroskopijom, termičkom (TG/DTA) analizom i određivanjem kapaciteta katjonske izmene, a polazne i neadsorbovane količine uranijum jona su određene fluorimetrijski. Eksperimenti su sprovedeni da se ispita uticaj odnosa čvrsto/tečno, $\mathrm{pH}$ i vremena na adsorpciju uranijum jona na zeolitu. Utvrđeno je da tretman sa kiselinama zeolita povećava adsorpciju uranijum jona. Najviši indeks adsorpcije imao je uzorak zeolita modifikovan sa hlorovodoničnom kiselinom. Dobijeni rezultati adsorpcije na $\mathrm{H}$-zeolitu su izračunati prema Langmirovom modelu.

Ključne reči: zeolit-klinoptilolit, modifikacija kiselinom, adsorpcija uranil-jona

Naučni rad

Rad primljen: 24. 05. 2016.

Rad prihvaćen: 22. 07. 2016.

Rad je dostupan na sajtu: www.idk.org.rs/casopis 